\title{
Barriers to the Growth of SMEs: Empirical Evidence from Algeria
}

Submitted 15/03/21, $1^{\text {st }}$ revision 08/04/21, $2^{\text {nd }}$ revision 29/04/21, accepted 20/05/21

\section{Hichem Sofiane Salaouatchi ${ }^{1}$, Olivier Colot $^{2}$, Youcef Boudella ${ }^{3}$, Mohamed Abdelkarim Chekirine ${ }^{4}$, Adja Hamida ${ }^{5}$, Mohamed Habaina ${ }^{6}$, Salima Khamadj ${ }^{7}$}

Abstract:

Purpose: This paper aims to study the barriers to SMEs' growth by the typology of entrepreneurs in the Algerian context.

Design/Methodology/Approach: We used the Ahmad and Hoffman model (2007) to determine the different blocking factors. The breakdown of these different barriers is divided into four types, internal barriers, micro external barriers, macro external barriers, and infrastructure barriers in a sample of 57 SMEs located in the Wilaya of Algiers.

Findings: The results show that the leaders of Algerian SMEs are mainly of the leadership type favoring independence indefinitely, which constitutes a barrier to growth. There is also a significant link between growth and reinvested earnings, and SME managers reinvest little of this. In addition, SME managers perceive that external barriers influence the growth of their enterprises than internal barriers.

Practical Implications: This study contributes to understanding barriers to SME growth by the typology of entrepreneurs in a particular context, which is Algeria. In practical terms, these results determine the barriers or constraints to the growth of our sample's industrial SMEs to allow an objective diagnosis for the main aspects.

Originality/value: This article innovates a new research context and adds to the existing literature by presenting new evidence about the obstacles to the growth of SMEs.

Keywords: SMEs, typology, growth, barriers to growth, entrepreneurs, Algeria.

JEL Codes: M12, M13, D92, G32.

Paper type: Research paper.

\footnotetext{
${ }^{1}$ Ecole des Hautes Etudes Commerciales, Laboratory MPI, Algeria \& GRM-UCA, Université Nice Côte d'azûr, France, hs.salaouatchi@hec.dz;

${ }^{2}$ Warocqué School of Business and Economics, University of Mons, Belgium,

Olivier.Colot@umons.ac.be;

${ }_{3}^{3}$ Faculty of Economics, Business and Management Sciences, FSECSG, Alpec Laboratory,

M'hamed Bougara Boumerdes University, Algeria

y.boudella@univ-boumerdes.dz

${ }^{4}$ Ecole des Hautes Etudes Commerciales, Algeria, k.chekerine@hec.dz;

${ }^{5}$ Warocqué School of Business and Economics, University of Mons, Belgium \& REIEM,

Ecole Supérieure de Commerce, Algeria, adja.hamida@student.umons.ac.be;

${ }^{6}$ Ecole Supérieur de Commerce, Algeria, m habbaina@esc-alger.dz;

${ }^{7}$ Ecole des Hautes Etudes Commerciales, Algeria, salima.kh33@yahoo.com;
} 


\section{Introduction}

The sphere of the economy in the late twentieth century gave rise to extensive literature and debates about globalization, knowledge-based economy, local development, and even the importance of small and medium-sized enterprises (Absesselam et al., 2000).

SMEs in this context is a critical vector in the socio-economic development of an economy, and for half a century, it has become an important economic actor. For example, an SME represents an alternative to reducing unemployment (Salehi, 2004). SMEs are used to optimize local resources and play an essential role in increasing gross domestic production (GDP) and changing export rates (Friis et al., 2002). SMEs have become, in recent years, a subject of interest for numerous specialists; they raise great questions and offer an enormous field of study and research (Lash and Yami, 2008). Following the emergence of multinational enterprises, research on SMEs has become an object that attracts economists, psychologists, and others. Many researchers and experts see this entity as the engine of economic growth (Carree and Thurik, 2006). Most research focuses on an SME with a high growth the gazelles (the companies employ between 50 and 250 employees, and among them, some show exceptional performances (for example, the criterion of a rate of $20 \%$ for four consecutive years, they are called « gazelles») (Kheladi, 2012), which contributed by its significant growth in turnover to boost the growth of the state budget and participates in the creation of employment and productivity (Minniti, 2008). These researches have helped decipher the critical success factors and constraints faced by SMEs in their internal and external environment. The research carried out on firms with experiences of failures will serve companies in economic activity (Ahmad and Hoffman, 2007).

In the case of Algeria, and since the late 1980s, the country has embarked on a transition from its economic environment, moving from a planned economy to a market economy. Algeria has an average of 22 SMEs per 1000 inhabitants $(820,738$ SMEs in the 1st quarter of 2014 according to the statistical bulletin from the Ministry of Industry and Mines of Algeria, $\left.\mathrm{n}^{\circ} 25\right)$. This number is low about international standards (the lowest rate is 45 SMEs per 1,000 inhabitants) (Gharbi, 2011). In other words, Algeria needs more than 1 million 700 thousand enterprises to allow a serious revival of the national economy. This has led Algeria and, since the 1990s, has provided significant resources for the creation of SMEs (Buenstorf, 2007), by setting up several support organizations, such as the National Youth Employment Support Agency (ANSEJ) in 1996, the National Unemployment Insurance Fund (CNAC) in 1994.

In our paper, we analyze SMEs' growth and development prospects (Greiner, 1972) in the shadow of the constraints to growth through research on a group of entrepreneurs in a territory (Abedou et al., 2006). 


\section{Literature Review}

In the early 1960s, researchers attempted to identify the entrepreneur's profile, the creator, the craftsman, the captain of industry, the innovator, the executive of a medium enterprise, etc. These studies have tried to argue the traits of skills that the "performing" entrepreneur should have (Marchesnay and Messeghem, 2011). The advances in research in entrepreneurship theory (Acs et al., 2005) have emerged, giving rise to two typologies of entrepreneurs.

\subsection{The First Type of SME Leaders in Relation to Growth is Called "SIG"}

Indeed, the first concern of this entrepreneur is to ensure the sustainability of his business. It focuses on the conservation and accumulation of its capital. The company falls under personal and family patrimony (Salaouatchi et al., 2017), and it must be managed by a "good father of the family." He wants to pass it on to his son or his children or sell it at a reasonable price. Secondly, the "SIG" is encouraged by the desire to remain independent; independence manifested in terms of the disposition of its patrimony.

Consequently, the SIG is reluctant to increase the capital by contribution to external partners; it will also be reluctant to go into long-term debt with banks, provided that this debt allows the banker to exercise a right of patrimonial regard (example: a participation loan). The use of self-financing will therefore be the rule; indebtedness is the exception. Finally, the growth appears only because of the search for patrimonial accumulation; it is not an end (Marchesnay, 1991)

Quite generally, it is observed that the "SIG" has a technical form instead. Its vision of the activity is somewhat introverted and focused on production problems. Its external field of vision remains narrow; it tends to firmly retain its relations with suppliers, customers, and colleagues. Therefore, commercial prospecting, for example, remains sporadic, as evidenced by the absence of commercial staff, which is assimilated to delivery and traditional logistics (Marchesnay, 1991).

This type of entrepreneur flourishes in low turbulent industries, highly accessible, not very complex (Audretsch, 2007). Their chain relationships are well established, and they offset the risks of dependence through loyalty. Their competitive advantage is based on the mastery of a trade, which can lead to a very favorable competitive positioning, as soon as this control can lead, in terms of a generic strategy (Marchesnay, 1991), either to a lower cost or to a positive differentiation of its activity, due to more attentive services towards the needs of the customer, closer and more interactive (Marchesnay and Messeghem, 2001). The enterprise managed by a SIG has a meager rate of return but hides an accumulation of cash capital and a large cash flow (Marchesnay and Messeghem, 2001). However, (Marchesnay, 1991) points out the negative points of this type, through 6 points, which are:

- First, the enterprise is often very vulnerable. It may be in difficulty as soon 
as more aggressive competitors enter the market. The absence of business intelligence then becomes a factor of blindness, and the entrepreneur does not have the reaction capacities which enable him to adapt to the new conditions of the industry.

- Secondly, the company risks being dependent on its customers and suppliers and, consequently, on their strategic objectives. Exclusive contracts and subcontracting contracts are rarely signed for eternity. Under these conditions, the small enterprise risks seeing part of its value "extorted" by the partner through the transaction relationship.

- Thirdly, the behavior of the entrepreneur is paternalistic. The significant risk here is the transmission of power; Increasing education, opposition to the father, children, or professionalism, for the potential buyer create inevitable conflicts in the design of the strategy, which many SMEs do not recover.

- Fourthly, the process of developing the strategy takes place outside of any procedure. The "SIG" is more of a reflexive trend. Its strategy is of incremental gradualist type because it is gradually being developed as decisions are made; this gradualism is related to rather reactive behavior, so the entrepreneur becomes aware of a problem, following an "incident" the environment, and reacts accordingly. As we have pointed out, this type of strategic process is dangerous as soon as disturbances occur in the environment.

- Fifthly, the head of an enterprise, "SIG," is driven by a globalist vision of his company. We can guess that he is highly centralizing. The information goes back to him, and he makes most decisions. This information and decisionmaking system can be suitable for simple structures, where a function predominates: a commercial function in the distribution, a function of production in agriculture or industry. However, in most industries, the foundations of value-added have changed dramatically. In the « value chain» according to Porter, the transformation activity is progressively supplanted by other vital functions: marketing, product design, processes, logistics, administration, etc.

However, in a small organization, the management system is an interactive whole. On the one hand, the three levels (finalization, administration-coordination, and operation-execution) vertically interact (any problem is likely to have one of three levels: Let us consider the "letting go" of a large customer). On the other hand, the various horizontal functions are closely intertwined. As a result, the head of an enterprise SIG may not be able to master all aspects of the management system and cannot perceive the depth of some external changes (Aragon-Sanchez et al., 2005). Consequently, the research hypothesizes can be stated as:

H1: The leaders of Algerian SMEs are mainly of the leadership type favouring independence indefinitely, finally the growth "SIG" which constitutes a barrier to growth.

H2: The ownership of the family in capital influences the growth of SMEs. 
2.2 The Second Type of Entrepreneur Favors Growth, Autonomy and Sustainability Henceforth «GAS»

As opposed to the "SIG," the "GAS" is concerned with growing activity or with the growth of its activities (Marchesnay and Messeghem, 2001). The "GAS" is primarily motivated by "blows," which gets close to the "opportunist" entrepreneur, unlike the "self-employed" entrepreneur. It is about finding activities that can be susceptible and allow for high profits with high risks. Moreover, the "GAS" is primarily guided by the search for the autonomy of the decision. As a result, it is not reluctant to involve foreign people in its capital; for all that, it retains a discretionary feature of decisions and management autonomy.

Finally, the "GAS" is interested in the perpetuation of its business if it is justified by obtaining income more "maximizing" than "satisfactory" in the long term. The "GAS" is, therefore, more mobile, more individualistic too. However, there is nothing to prevent "GAS" from being transformed into "SIG" if it can protect its market, to become less vulnerable (an industry that has become less accessible, less turbulent, less complex, or with controlled complexity).

McMahon's (2001) longitudinal study of 871 Australian SMEs reveals three growth profiles among leading owners (Bosma et al., 2001). The first, which represents $70 \%$ of the participating companies, is made up of SMEs headed by senior owners who do not necessarily target the growth of their enterprise. Established mainly to provide them with income and employment, even after 20 years of existence, SMEs run by this type of owner-managers always have fewer than 20 people employed. The second profile represents $25 \%$ of the sample. Compared to the first, SMEs in this second profile are led by leaders with modest growth aspirations. According to the author, this controlled growth can be imposed by the sector or simply by the type of environment in which SMEs operate. After about fifteen years, these SMEs have less than 100 people in their jobs. Finally, the third profile, made up of $5 \%$ of participating SMEs, represents those led by leaders with strong growth ambitions. According to McMahon (2001), these enterprises are often innovative, aspire to international markets, and have characteristics of future large companies. After 15 years, the latter type of SME employs more than 100 people. This explains the extent to which growth is not an objective for all SME owners, without questioning their reason for existence (St-Pierre Cadieux, 2001).

If we refer to another survey on the development strategies of SME managers in France conducted in 1991 by the Equipment Credit for SMEs - CEPME, one of the ancestors of OSEO, some results, although ancient, seem to remain topical judging by the evidence gathered in 2008 (OSEO, 2009): In 1991, 30\% of SME managers with between 3 and 500 employees preferred a business strategy in their existing markets rather than in new markets. In the survey conducted in 2008 for this publication, $27 \%$ of SME managers and 10 to 250 employees declared that they did not wish to expand their enterprise, compared with $25 \%$ who said they could not develop it. 
From these studies, we can conclude that the SME entrepreneur can be the first trigger of the growth process or the first brake of the latter. To better understand this typology of entrepreneur of the SME and its impact on growth, we will try to test SMEs in Algeria, in a territory "Wilaya of Algiers." Therefore, the research hypotheses are:

H3: There is a significant link between growth and reinvested earnings as well as SME managers reinvest little of this result.

H4: SME managers perceive that external barriers have more influence on the growth of their enterprises than internal barriers.

\section{Methodology}

We used a random sampling method, and administering the questionnaire was done in a semi-guided manner to explain the heads of enterprises and our research objectives. We used the chi-square test and a simple regression model to analyze the research data. The empirical analysis threshold is taken at a level of significance of $(\propto=10 \%)$. The SPSS software processes the data 20 .

\subsection{Presentation of the Sample}

The empirical study focuses on a sample of 57 private companies (Algerian SMEs), all located in the wilaya of Algiers. All legal forms are taken into consideration (SARL, EURL, SNC, SPA, independent). The database used is that of the Directorate of Industry and SMEs and the Promotion of Investment of the wilaya of Algiers; we have established our research to SMEs located in the industrial zones or out of industrial zones.

Table 1. The industrial zones that were the subject of the investigation

\begin{tabular}{|l|c|}
\hline \multicolumn{1}{|c|}{ Industrial Zone } & The municipality \\
\hline AMMARA & CHERAGA \\
\hline AL KARIA & CHERAGA \\
\hline OULED FAYET industrial zone BOUCHAOUI road & OULED FAYET \\
\hline BABA ALI & BIRTOUTA \\
\hline SIDI ABED & TESSALA EL MERDJA \\
\hline Industrial zone of the municipality of DOUERA & DOUERA \\
\hline EL ACHOUR industrial zone & EL ACHOUR \\
\hline ZOUINE zone & SAOULA \\
\hline
\end{tabular}

Source: Own creation.

We were able to note the following remarks from our visit to the industrial zones:

- All the enterprises located in the industrial zones are rental enterprises with the private owners;

- The enterprises located in the industrial zones are largely commercial and not industrial;

- Infrastructure (gas, water, electricity, road, etc.) are available in these zones, but heads of enterprises protest the quality of these services (cuts, 
deterioration of the state for roads).

In the following, we present all the variables collected in the framework of our empirical analysis.

\subsection{The Selected Variables and the Adaptation of the Ahmad and Hoffman Model}

Considering our problem and the framework of the analysis chosen through the Ahmad and Hoffman model (2007), we decided to divide the variables into three main types:

- Growth variables;

- Identification variables (company / manager);

- The variables related to the growth barriers that have been divided by following the division of the theoretical part, under 4 levels:

- Variables related to the manager.

- Variables related to the internal environment of the SME.

- Variables related to the micro external environment of the SME.

- Variables related to the external macro environment of the SME.

Figure 1. The relation between the barriers to the growth and the growth criteria of the enterprise

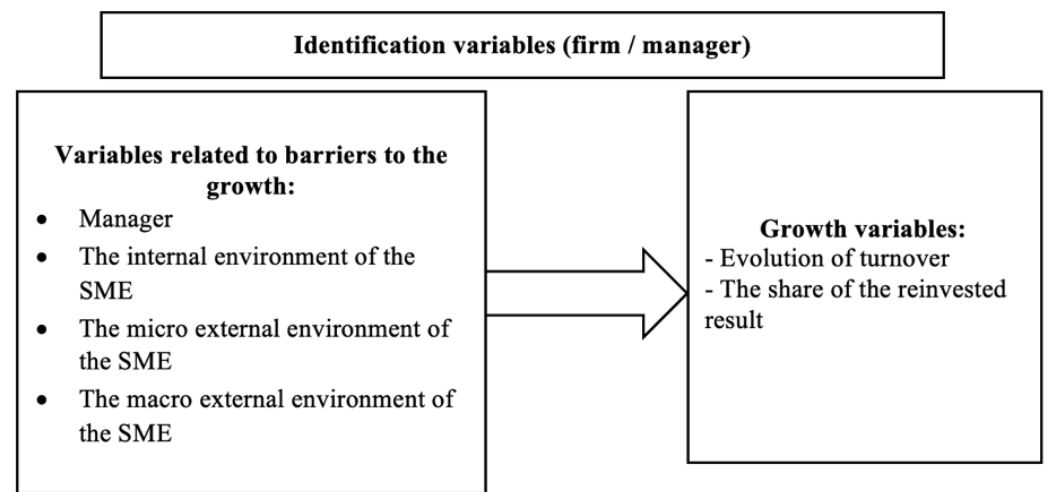

Source: Own creation.

In our paper, we chose only the following variables to answer our research problem:

\subsubsection{Variables Related to the Manager}

- GROINT: Growth intent;

- OPENGAS: Opening of the company's capitals to other investors;

- RISK: Is the activity risky in relation to the manager.

\subsubsection{Variables Related to the Internal Environment of the SME}

- INFLFAM: Influence of family on decision-making. 


\subsection{The Legal Status}

SARL account for $51 \%$ of the sample, followed by independent with $26.3 \%$, EURL represent $18 \%$ and a low representation of SPA and SNC with only $2 \%$. It can be deduced that firms account for $73.7 \%$ of the sample and $26.3 \%$ for independent.

Figure 2. The legal forms of the enterprises in the sample

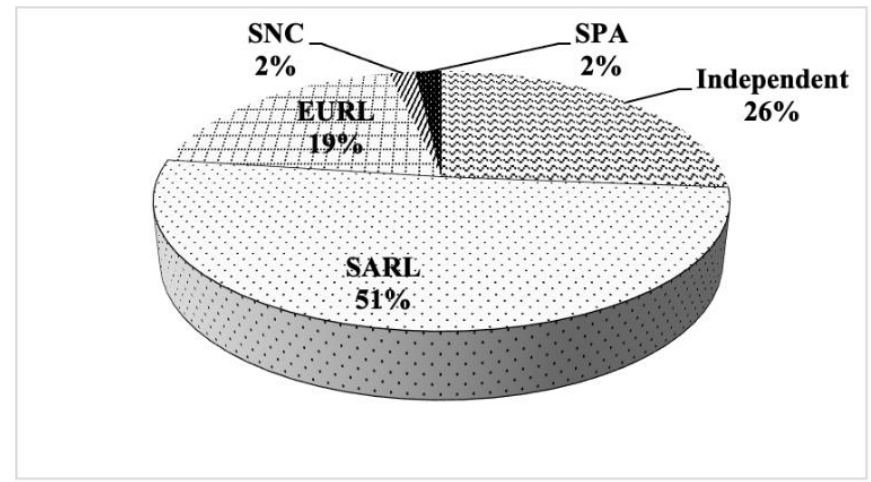

Source: Own creation.

\subsection{The Classification of SMEs in the Sample}

We followed a classification based on the definition criteria of SMEs in Algeria, according to Law 01-December 18 December 12, 2001, laying down the law for the promotion of small and medium-sized enterprises. The results are presented in Figure 3 , it represents the breakdown of SMEs in the sample. The number of small firms is relatively the largest with 26 TPE, or $45.6 \%$ of the sample, followed by PE with $35 \%$, ME represents $19 \%$.

Figure 3. Typology of SMEs in the sample by size

Source: Own study.

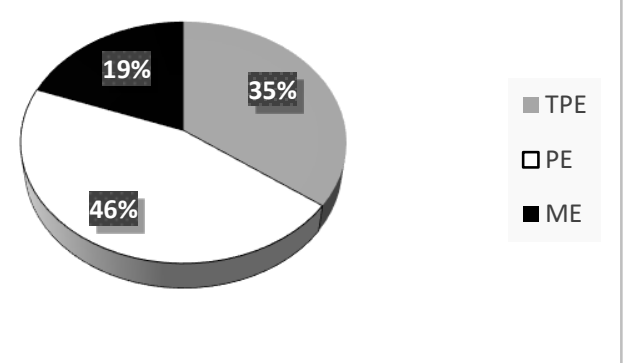

\subsubsection{The Growth Phase According to the Age of the SMEs in the Sample}

The survey was based on firms with more than 3 years of existence, which represent $96.5 \%$ of the sample. 
Table 2. Typology of SMEs in the sample according to age group / growth phase

\begin{tabular}{|l|c|c|c|c|c|c|}
\hline Age range & Start & Growth & Maturity & Decline & $\begin{array}{c}\text { Number } \\
\text { in the } \\
\text { sample }\end{array}$ & $\begin{array}{c}\text { Percentage } \\
\text { in the } \\
\text { sample }\end{array}$ \\
\hline $\begin{array}{l}\text { Less than 3 } \\
\text { years }\end{array}$ & 3 & 0 & 0 & 0 & 3 & $5,26 \%$ \\
\hline $\begin{array}{l}3 \text { years and } \\
\text { over }\end{array}$ & 0 & 35 & 15 & 4 & 54 & $94,74 \%$ \\
\hline $\begin{array}{l}\text { Number in } \\
\text { the sample }\end{array}$ & 3 & 35 & 15 & 4 & 57 & $/$ \\
\hline $\begin{array}{l}\text { Percentage in } \\
\text { the sample }\end{array}$ & $5,26 \%$ & $61,40 \%$ & $26,32 \%$ & $7,02 \%$ & $/$ & $100 \%$ \\
\hline
\end{tabular}

Source: Own creation.

The enterprise's growth rate stands at $61.4 \%$. Mature firms account for $26 \%$ of the sample while declining, and start-up firms account for $7 \%$ and $5 \%$, respectively. The chi-square test shows a significant relationship between the breakdown of SMEs in the sample by age group and growth phases.

Table 3. Chi-square test between age group and growth phase

\begin{tabular}{|l|l|c|c|}
\cline { 2 - 4 } \multicolumn{1}{c|}{} & Value & DDL & $\begin{array}{l}\text { Asymptotic } \\
\text { (bilateral) }\end{array}$ \\
\hline Pearson chi-square & $57,000^{\mathrm{a}}$ & 3 &, $000^{* *}$ \\
\hline Verisimilitude ratio & 23,506 & 3 &, 000 \\
\hline Linear association by linear & 11,993 & 1 &, 001 \\
\hline Number of valid observations & 57 & $/$ & $/$ \\
\hline
\end{tabular}

Source: Own creation.

\subsubsection{Family Firms}

Most of the work on Algerian SMEs indicates the family character that dominates most. We took this aspect, and we had the following results for the family's participation in the enterprise's capital. Family SMEs represent more than half of our sample (63.2\%). On the other hand, non-family SMEs represent $36.8 \%$ of our sample.

Table 4. The share of family SMEs in the sample

\begin{tabular}{|c|c|c|}
\hline $\begin{array}{c}\text { The participation of } \\
\text { the family in the } \\
\text { capital of the firm }\end{array}$ & $\begin{array}{c}\text { Number in the } \\
\text { sample }\end{array}$ & $\begin{array}{c}\text { Percentage in the } \\
\text { sample }\end{array}$ \\
\hline No & 21 & $36,8 \%$ \\
\hline Yes & 36 & $63,2 \%$ \\
\hline Total & 57 & $100 \%$ \\
\hline
\end{tabular}

Source: Own creation.

\subsubsection{Industrial Sub-sector}

For the industrial sub-sector, we opted for the division used in the statistical bulletins of the Ministry of Industry for industrial SMEs (or SMIs). 
Figure 4. The typology of SMEs in the sample according to the industrial subsectors

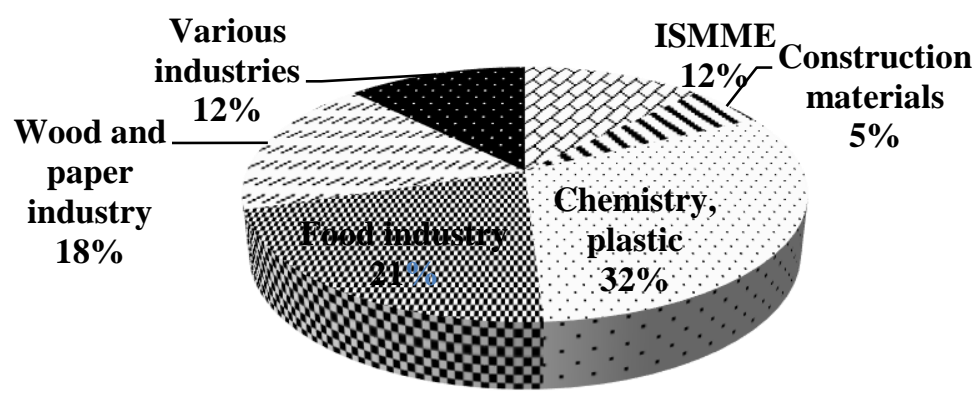

Source: Own creation.

SMEs active in chemicals and plastics account for the largest share of our sample, $32 \%$, followed by the agro-food industry, or $21 \%$. The wood and paper industry accounts for $18 \%$. The rest is shared between various industries (12\%), ISMME $(12 \%)$, and building materials $(5 \%)$. The absent industrial sub-sectors are 3 : Textile Industry, Leather Industry, and Mining and Quarrying. This is due to the virtual absence of these activities in the municipalities.

\section{Results and Discussion}

We have focused our attention on the SME executive according to three essential aspects, which are:

\subsection{Variables Related to the Executive}

We have focused our attention on the SME executive according to three essential aspects, which are:

- Intention of growth (INTGRO).

- Opening of the enterprise's capital to other investors (OPENGAS).

- The activity is risky or not in relation to the manager (RISK).

\subsubsection{Intention of Growth}

We asked a question about the intention to grow, merging the intention with the power to do so, and the results are summarized.

Table 5. Growth intentions among SMEs in the sample

\begin{tabular}{|c|c|c|}
\hline $\begin{array}{l}\text { Do you intend to launch your business in a new phase of } \\
\text { development? }\end{array}$ & $\begin{array}{c}\text { Number in } \\
\text { the sample }\end{array}$ & $\begin{array}{c}\text { Percentage in } \\
\text { the sample }\end{array}$ \\
\hline No, you do not want to grow your business & 2 & $3,5 \%$ \\
\hline $\begin{array}{l}\text { You would like to grow your business, but you } \\
\text { cannot do it }\end{array}$ & 31 & $54,4 \%$ \\
\hline Yes, and its development phase is under way or is & 24 & $42,1 \%$ \\
\hline
\end{tabular}




\begin{tabular}{|l|l|l|}
\hline about to be & & \\
\hline Total: & 57 & $100 \%$ \\
\hline
\end{tabular}

Source: Own creation.

It is noteworthy that $96.5 \%$ of respondents would like to expand their activities, but only $42.1 \%$ are in the development phase. These results show the dominance of SME development intention among its managers, but it faces many problems that slow down or impede the process.

\subsubsection{Opening of the Company's Capital to Other Investors}

Through the administered questionnaire, we have had results showing the mistrust of the heads of SMEs to the opening of capital, this is represented in Table (6). These results confirm resistance to the opening of capital in 42 SMEs, 25 of which are highlighted the intention of growth with the inability to carry it out. This resistance can be described as an obstacle to the growth of SMEs. The non-significance is explained by the 2 cases that chose the answer "No" for intent to grow. The significance is very high if we took only 55 SMEs.

Table 6. Opening of capital according to the intention and power of SME development

\begin{tabular}{|l|c|c|c|c|}
\cline { 2 - 4 } \multicolumn{1}{c|}{} & \multicolumn{2}{|c|}{$\begin{array}{c}\text { Opening of } \\
\text { the capital }\end{array}$} & \multirow{2}{*}{ Total } & \multirow{2}{*}{$\begin{array}{c}\text { Total } \\
\%\end{array}$} \\
\cline { 2 - 4 } & No & Yes & & \\
\hline $\begin{array}{l}\text { No, you do not want to grow your } \\
\text { business }\end{array}$ & 2 & 0 & 2 & $3,5 \%$ \\
\hline $\begin{array}{l}\text { You would like to grow your business, } \\
\text { but you cannot do it }\end{array}$ & 25 & 6 & 31 & $54,4 \%$ \\
\hline $\begin{array}{l}\text { Yes, and its development phase is under } \\
\text { way or is about to be }\end{array}$ & 15 & 9 & 24 & $42,1 \%$ \\
\hline Total: & 42 & 15 & 57 & $100 \%$ \\
\hline
\end{tabular}

Source: Own creation.

Table 7. Chi-square test between « intention and power of growth » and « intention to open capital»

\begin{tabular}{|l|c|c|c|}
\cline { 2 - 4 } \multicolumn{1}{c|}{} & Value & DDL & $\begin{array}{c}\text { Asymptotic significance } \\
\text { (bilateral) }\end{array}$ \\
\hline Pearson chi-square & $4,009 \mathrm{a}$ & 2 &, 135 \\
\hline Verisimilitude ratio & 4,404 & 2 &, 111 \\
\hline Linear association by linear & 3,917 & 1 &, 048 \\
\hline Number of valid observations & 57 & $/$ & $/$ \\
\hline
\end{tabular}

Source: Own creation.

\subsubsection{The Managers' View of Risk}

The managers' views differed concerning risk, but for the sample studied, most of these managers $(84.2 \%)$ confirmed the risk incurred by the committed investments, compared with $15.8 \%$ who emphasize the absence of risk about the investments made. 
Hichem Sofiane Salaouatchi, Olivier Colot, Youcef Boudella, Mohamed Abdelkarim Chekirine, Adja Hamida, Mohamed Habaina, Salima Khamadj

Table 8. The leaders' vision about the risk

\begin{tabular}{|c|c|c|}
\hline $\begin{array}{c}\text { Do you take risks to } \\
\text { invest? }\end{array}$ & $\begin{array}{c}\text { Number in the } \\
\text { sample }\end{array}$ & $\begin{array}{c}\text { Percentage in the } \\
\text { sample }\end{array}$ \\
\hline Yes & 9 & $15,8 \%$ \\
\hline No & 48 & $84,2 \%$ \\
\hline Total: & 57 & $100 \%$ \\
\hline
\end{tabular}

Source: Own creation.

For the explanation of these results, we can emphasize on the one hand, for the managers who have chosen the first response, confirm this risk by the presence of fierce competition, whether in the formal or informal sector (The informal sector) is exempt from tax and regulatory procedures, which gives it an advantage in terms of price (tax charges) or even unfair competition practices (e.g., imitation of the product using the same trademark illegally). On the other hand, the managers who chose the second answer: explain their opinion by choosing a mature activity that does not require much investment.

\subsection{Influence of the Family on the Decisions Taken in the Enterprise}

This section will focus our analysis on the family variable and its influence on the decisions taken in the SME. Through our questionnaire, we collected information about the influence of the family on the management of SMEs. By analyzing the research results, we find a significant link between the influence of the family and its participation in decision-making in SMEs. Even in literature, we noted that family businesses have a specific management mode; we will try to analyze the family SMEs in our sample according to 2 axes: According to the influence of the family on the decisions of the SME and according to their Business Performance. We note that the participation of the family in the capital makes it possible to influence the decision of the enterprise; 35 of the SMEs report a weak influence, the rest of the SMEs (21 family enterprises and one non-family) emphasize the family influence Decisions in the SME by different degrees.

Table 9. The influence of the family according to its participation in the capital of the SMEs studied

\begin{tabular}{|c|c|c|c|c|c|c|c|}
\hline & \multicolumn{5}{|c|}{ Influence of the family in decisions made in SMEs } & \multirow[b]{2}{*}{ Total } \\
\hline & & $\begin{array}{c}\text { Very } \\
\text { small }\end{array}$ & Small & Average & High & Very high & \\
\hline \multirow{2}{*}{$\begin{array}{l}\text { Family } \\
\text { Firms }\end{array}$} & No & 21 & 0 & 1 & 0 & 0 & 22 \\
\hline & Yes & 14 & 2 & 7 & 3 & 9 & 35 \\
\hline \multicolumn{2}{|c|}{ Total: } & 35 & 2 & 8 & 3 & 9 & 57 \\
\hline
\end{tabular}

Source: Own creation.

The chi-square test shows that there is a significant relationship between the family's participation in the capital of the SME and its influence on the decisions taken. 
Table 10. Chi-square test between " the participation of the family in the capital of the SME » and " its influence on the decisions taken »

\begin{tabular}{|l|l|c|c|}
\hline & Value & DDL & $\begin{array}{c}\text { Asymptotic significance } \\
\text { (bilateral) }\end{array}$ \\
\hline Pearson chi-square & $17,864^{\mathrm{a}}$ & 4 &, $001^{* *}$ \\
\hline Verisimilitude ratio & 22,888 & 4 &, 000 \\
\hline Linear association by linear & 15,250 & 1 &, 000 \\
\hline $\begin{array}{l}\text { Number of valid } \\
\text { observations }\end{array}$ & 57 & $/$ & $/$ \\
\hline
\end{tabular}

Source: Own creation.

Table 11. The relationship between family SMEs and gazelles

\begin{tabular}{|l|c|c|c|c|c|c|}
\hline & \multicolumn{4}{|c|}{ The gazelles } & \multirow{2}{*}{ Total } & $\begin{array}{c}\text { Total } \\
\%\end{array}$ \\
\cline { 2 - 5 } & No & $\%$ & Yes & $\%$ & & $61,40 \%$ \\
\hline Family Firms & 26 & $45,61 \%$ & 9 & $15,79 \%$ & 35 & 62 \\
\hline Non-family Firms & 11 & $19,30 \%$ & 11 & $19,30 \%$ & 22 & $38,60 \%$ \\
\hline Total: & 37 & $64,91 \%$ & 20 & $35,09 \%$ & 57 & $100 \%$ \\
\hline
\end{tabular}

Source: Own creation.

We have compared the participation of the family with the type of SME (gazelle and non-gazelle) considering the rate defined by (Birch, 199) whose average turnover is $20 \%$ for 4 years. We obtained the results summarized in Table (11).

For non-familial SMEs we had the same number between gazelles and non-gazelles. On the other hand, we note that $74 \%$ of family businesses are not gazelles for family SMEs. This result brings us back to the fact that the family can be an obstacle to the growth of the SME. The chi-square test shows that the relationship is significant between «Family SMEs» and the division that differentiates between «gazelles and non-gazelles».

Table 12. Chi-square test between family SMEs and gazelles

\begin{tabular}{|c|c|c|c|c|c|}
\hline & Value & DDL & $\begin{array}{l}\text { Asymptotic } \\
\text { significance } \\
\text { (bilateral) }\end{array}$ & $\begin{array}{c}\text { Exact } \\
\text { significance } \\
\text { (bilateral) }\end{array}$ & $\begin{array}{c}\text { Exact } \\
\text { significance } \\
\text { (unilateral) }\end{array}$ \\
\hline Pearson chi-square & $3,498^{\mathrm{a}}$ & 1 &, $061^{*}$ & & \\
\hline $\begin{array}{l}\text { Correction for } \\
\text { continuity }{ }^{b}\end{array}$ & 2,513 & 1 &, 113 & & \\
\hline Verisimilitude ratio & 3,469 & 1 &, 063 & & \\
\hline Fisher's exact test & & & & ,088 & 057 \\
\hline Linear association by linear & 3,437 & 1 & ,064 & & \\
\hline $\begin{array}{l}\text { Number of valid } \\
\text { observations }\end{array}$ & 57 & & & & \\
\hline
\end{tabular}

Source: Own creation.

\subsection{Growth-Related Variables (Relationship Between Growth and Reinvested Result)}

By crossing quantitative variables linked to growth, which are, the average change in 
turnover (ACT), and the average share of the reinvested result (ASRR), we have found a significant difference between the two variables according to the linear regression. The results are summarized in Figure (5).

Figure 5. Relationship between growth and results reinvesting

$$
\begin{gathered}
\mathbf{A C T}=\mathbf{1 2 , 3 9 4}+\mathbf{0 , 2 2 2 A} \mathbf{S R R}+\boldsymbol{\mu} \\
(3,508) *(2,219)^{*} \\
\mathrm{~F}^{*}=4,924 \\
\mathrm{R}=0,287 \quad \mathrm{R}^{2}=0,082 \quad \propto=10 \%
\end{gathered}
$$

Source: Own creation.

There is a positive relationship between the result reinvested and the turnover within a significance threshold of 5\%. The correlation coefficient ratio is low, estimated at $28.7 \%$.

The reinvested result explains $8.2 \%$ of the turnover growth of our sample; the Fisher test demonstrates that the quality of the model is significant at the $5 \%$ threshold. These results show that the reinvested result contributes with a low rate to the growth of the SMEs in the sample, which explains why the SMEs of the sample reinvest little investment in their future projects.

Table 13. SMEs in the sample according to the share of the reinvested result

\begin{tabular}{|l|c|c||c|c|}
\cline { 2 - 4 } \multicolumn{1}{c|}{} & $\begin{array}{c}\text { Number } \\
\text { in the } \\
\text { sample }\end{array}$ & $\begin{array}{c}\text { Percentage in the } \\
\text { sample }\end{array}$ & Average & Standard deviation \\
\hline Less than $50 \%$ & 46 & $80,7 \%$ & 29,5263 & 19,46 \\
\hline More than $50 \%$ & 11 & $19,3 \%$ & Minimum & Maximum \\
\hline Total: & 57 & $100 \%$ & 5 & 100 \\
\hline
\end{tabular}

Source: Own creation.

It is noted that more than $80 \%$ of SMEs reinvest less than $50 \%$ of their results. The average of 29.52 and the standard deviation 19.46 confirm that most companies do little reinvestment. The minimum reinvestment rate is $5 \%$ while the maximum reinvestment rate is $100 \%$.

\subsection{Variables Related to Manager and to the Internal Environment of the SME}

To explain these results, we had direct conversations with the leaders of a few SMEs. These managers give different explanations according to the environment and the size of the companies of which they are, we made the following observation: (1) The inadequacy of available capital to finance growth, the results of which they call low; (2) The problem of renting premises and lands; (3) Much of the reinvested results are 
intended to offset inflation in the prices of raw materials.

The explanations given by SME managers are not enough to describe the situation well. Since each SME is specific in its management, internal and external environment, we, therefore, deemed it necessary to deepen the analysis by analyzing the internal and external environment.

\subsection{Other Internal and External Barriers}

We have noted the difficulty of determining all the barriers for SMEs, given the specificities of each SME. We tried to give the most important (according to Ahmad and Hoffman, 2013). We opted for a specific cutting for the other barriers under 4 types: Internal barriers (6); Micro External Barriers (3); Macro external barriers (5); Infrastructure problems (6).

In analyzing the most mentioned barriers we found that:

- The problem of recruitment and competition are the most mentioned problems (93\% of the entrepreneurs questioned expressed the importance of these two problems, which describes them as major problems).

- We also note that the average of the ticked responses favors micro external environment variables (average of 39.67), followed by macro external variables (mean 33.4), and at the end, internal variables (mean of 22.5).

- The few mentioned problems are: The management problem (almost 32\%) and the problem of inadequate proper funds (30\%), and finally the renewal of investors' engagement (11\%).

Table 14. Other barriers to growth

\begin{tabular}{|c|c|c|c|c|c|}
\hline & $\mathrm{NO}$ & No $\%$ & YES & Yes \% & Total \\
\hline Competition problem & 4 & $7,02 \%$ & 53 & $92,98 \%$ & 57 \\
\hline Recruitment problem & 4 & $7,02 \%$ & 53 & $92,98 \%$ & 57 \\
\hline Supplier problem & 12 & $21,05 \%$ & 45 & $78,95 \%$ & 57 \\
\hline Inflation problem & 15 & $26,32 \%$ & 42 & $73,68 \%$ & 57 \\
\hline Electricity problem & 21 & $36,84 \%$ & 36 & $63,16 \%$ & 57 \\
\hline Machine problem & 22 & $38,60 \%$ & 35 & $61,40 \%$ & 57 \\
\hline Facilities problem & 23 & $40,35 \%$ & 34 & $59,65 \%$ & 57 \\
\hline Taxation problem & 24 & $42,11 \%$ & 33 & $57,89 \%$ & 57 \\
\hline Telephony problem & 25 & $43,86 \%$ & 32 & $56,14 \%$ & 57 \\
\hline internet problem & 26 & $45,61 \%$ & 31 & $54,39 \%$ & 57 \\
\hline Loss of key men & 32 & $56,14 \%$ & 25 & $43,86 \%$ & 57 \\
\hline Transport broblem & 34 & $59,65 \%$ & 23 & $40,35 \%$ & 57 \\
\hline Customer problem & 36 & $63,16 \%$ & 21 & $36,84 \%$ & 57 \\
\hline
\end{tabular}


Hichem Sofiane Salaouatchi, Olivier Colot, Youcef Boudella, Mohamed Abdelkarim Chekirine, Adja Hamida, Mohamed Habaina, Salima Khamadj

\begin{tabular}{|c|c|c|c|c|c|}
\hline Regulatory problem & 37 & $64,91 \%$ & 20 & $35,09 \%$ & 57 \\
\hline Return on investment & 38 & $66,67 \%$ & 19 & $33,33 \%$ & 57 \\
\hline Management problem & 39 & $68,42 \%$ & 18 & $31,58 \%$ & 57 \\
\hline Equity problem & 40 & $70,18 \%$ & 17 & $29,82 \%$ & 57 \\
\hline Water availability problem & 40 & $70,18 \%$ & 17 & $29,82 \%$ & 57 \\
\hline Casproblem & 43 & $75,44 \%$ & 14 & $24,56 \%$ & 57 \\
\hline Reinvestment problem & 51 & $89,47 \%$ & 6 & $10,53 \%$ & 57 \\
\hline
\end{tabular}

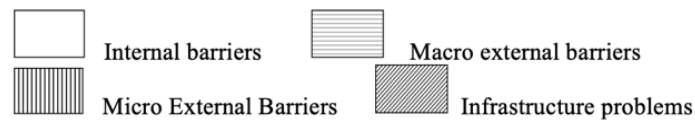

Source: Own creation.

\section{Conclusion}

From the literature review and the empirical study, we have found that SME is an essential vector in developed economies and a potential solution for developing countries like Algeria. Enterprises with problems or difficulties encountered in growth like governance and management problems, such as the case of confusion between the social interest and the personal interest of entrepreneurs.

Through our research, we have been able to determine the barriers or constraints to the growth of the industrial SMEs of our sample to allow an objective diagnosis for the main aspects, which are (the manager, the internal and external environment), from which the idea of the territory arises. We can thus answer the hypotheses proposed in our paper as follows:

- Validation of the first hypothesis;

- Partial validation of the second hypothesis;

- Validation of the third hypothesis;

- Validation of the fourth hypothesis.

\section{References:}

Abedou, A., Bouyakou, A., Lallement, M., Madoui, M. 2006. De la gouvernance des PMEPMI. Ed. L'harmattan, Paris, France.

Absesselam, R., Bonnet, J., Le Pape, J. 2000. An Explanation of the Life Span of New Firms: An Empirical Analysis of French Data. Working paper of Gemma-Lere, University of Caen.

Acs, J.Z., Audretsch, D.B., Braunerhjelm, P., Carlsson, B. 2005. The Knowledge Spillover Theory of Entrepreneurship. Working paper no 5326, London, Center for Economic Research.

Ahmad, N., Hoffman, A. 2007. A Framework for Addressing and Measuring Entrepreneurship. Paris, OCDE, Entrepreneurship Indicators Steering Group.

Ahmad, N., Hoffman, A. 2013. In the Entrepreneurship Panorama, OCDE Publishing. Aragon-Sanchez, A., Sanchez-Martin, G. 2005. Strategic Orientation, Management 
Characteristics, and Performance: A Study of Spanish Firms. Journal of Small Business Management, 43(3), 287-308.

Audretsch, D.B., Grilo, I., Thurik, A.R. 2007. Explaining Entrepreneurship and the Role of Policy: A Framework. In: Handbook of Entrepreneurship Research Policy, Audretsch, D.B, Grilo, I., Thurik, A.R. (Eds), Edward Elgar Publishing Limited, Cheltenham, UK and Northampton, MA.

Bosma, N., Wennekers, S., De Wit, G. 2001. Explaining and Forecasting the Number of Business Owners: The Case of Netherlands. Babson Entrepreneurship Research Conference, Jönkö, Sweden.

Buenstorf, G. 2007. Creation and Pursuit of Entrepreneurial Opportunities: An Evolutionary Economic Perspective. Small Business Economics, 28(4), 323-337.

Carree, M., Thurik, A.R. 2006. Understanding the role of entrepreneurship for economic growth. In: Carree, M.A., Thurik, A.R. (Eds.), The handbook of entrepreneurship and economic growth (international library of entrepreneurship series), 9-10.

Friis, C., Paulsson, T., Karlsson, C. 2002. Entrepreneurship and Economic Growth, A Critical Review of Empirical and Theoretical Research, Instituet För Tillväxpoulitiska Studier (Itps), Östersund.

Gharbi, S. 2011. Les PME/PMI en Algérie: Etat des lieux, Working paper no 238, ULCO / Research Unit on Industry and Innovation, Cahiers du Lab. RII.

Greiner, L.E. 1972. Evolution and Revolution as Organizations Grow. Hbr, Growth Phases, Harvard Business Review, 50(4), 37-46.

Kheladi, M. 2012. Le Développement local, Alger, Office Des Publications Universitaires (OPU), 104-105.

Lash, F., Yami, S. 2008. The Nature and Focus of Entrepreneurship Research in France over the last Decade: A French Touch? Entrepreneurship Theory and Practice, 32(2), 339-360.

Marchesnay, M. 1991. La PME: Une Gestion Spécifique, Economie Rurale, France, 206(1), $11-17$.

Marchesnay, M., Messeghem, K. 201. Cas de stratégie de PME et d'entrepreneuriat: 7 cas réels d'entreprise. France, Ems Editions, Colombelles, 194.

Marchesnay, M., Messeghem, K. 2001. Cas de Stratégie de PME. France, Ems Editions, Colombelles, 176.

Minniti, M. 2008. The Role of Government Policy on Entrepreneurial Activity: Productive, Unproductive, or Destructive? Entrepreneurship Theory \& Practice, 32(5), 770790 .

OSEO. 2009. Regards sur les PME, Freins à la croissance des PME à potentiel de développement, Observatoire des PME, 15, 5.

Salaouatchi, H.S., Aliouat, B., Saibi, S. 2017. Mise à niveau, Gouvernance et Performance de la PME Privée algérienne : le cas de la PME GCP «Jutop» 2004-2014. Revue Sciences Humaines, 48(B), 117-137.

Salehi, S. 2004. Méthodes de Développement des PME dans L'économie Algérienne. Revue des Sciences Economiques et Sciences De Gestion. Faculté des Sciences Economiques et de Gestion, Setif.

St-Pierre, J., Cadieux, L. 2001. La Conception de la Performance : Quels liens avec le Profil Entrepreneurial des Propriétaires Dirigeants de PME? Revue de l'entrepreneuriat, 10(1), 33-52. 